\title{
Analysis of Trade off Between Debt and Equity of Firms in Indian Cement Industry
}

\author{
Ashok Sengupta ${ }^{* 1}$ and Devesh Gupta ${ }^{2}$ \\ 1.* Research Scholar, Dr. APJ Abdul Kalam Technical University, Lucknow, (U.P.), India; e-mail : ashoksen.gupta@ rediffmail.com \\ 2. Professor, Department of Management, SSITM, Aligarh, (U.P.), India.
}

\section{Publication Info}

\section{Article history :}

Received : 03 ${ }^{\text {rd }}$ May, 2018

Accepted : $17^{\text {th }}$ May, 2018

DOI : $10.18090 /$ samriddhi.v10i01.6

Keywords :

EPS, Leverage Ratio, BSE

*Corresponding author :

Ashok Sengupta

e-mail : ashoksen.gupta@rediffmail.com

\begin{abstract}
Cement industry has a huge contribution to India's GDP and infrastructure development. Due to demand of cement new companies from outside also started functioning in our country but there are several problems which are faced by these industries. Companies are closed or merged due to lack of financial sustainability and capital structure problems. The study is based on the trade off relationship between debt and equity in the firm. In this study as a researcher, it has been tried to study and find out the relation of ROA, ROE, advantage ratios and correlation with EPS. For this, the sample size is 5 companies for BSE list (Bombay Stock Exchange) and about last ten years of data is studied. As cement industry is capital-centric in nature, this study will help the industry to understand the facts, which fulfill the financial objectives.
\end{abstract}

\section{INTRODUCTION}

$\mathrm{T}$ he long-term capital decision making is very important factor in business decision making. Capital budgeting procedure is based on long-term investment which helps to find out at what level company can generate maximum fund at a minimum rate with maximum profit level? Capital budgeting theories also give a brief idea in how much time period company gets a return. Capital structure decision helps to identify that how much debt a company has tolerated? The companies arrange long-term capital from two (1) Share capital (2) Debt Capital. In 1958, Miller Modigliani in his article wrote that firm's value is unaffected due to capital structure decision. They also suggested that if firms pay the taxes then it can adopt $100 \%$ debt finance strategies.

Firm's value in the market is uncertain and volatile in nature. Overture of debt capital can change the market for equity in a different way. Every firm has its own proportion of debt ratio which affect the value of firms adversely or favourably even the firm of same industry level has different proportionate of the debt-equity mix.

After MM approach in 1958, David Durant studied the concept of capital structure and gave two approaches related to capital structure first is Net Income Approach and other is Net Operating Income. In NI approach firm can lower its cost of capital which increases the value of the firm. The assumption in this approach is that, debt does not affect minds of investors at the time of investment. The second approach was Net Operating Income Approach, in this approach weightage average cost of capital of debt and equity is unvarying for any degree of leverage. Therefore, no optimum level of capital structure.

\section{REVIEW OF LITERATURE}

According to Lim (2012), the way firms generate the money to finance its business operations and the way it uses these financing options that he choose to its balance sheet are referred to firm's capital structure. It symbolizes the total capital of 
a firm in terms of equity debt blend to finance firm's operations.

According to Umar (2012), equity and debt are the main financing options used by all the firms.

San and Hang (2011) extended that firms overall operational growth by financing its assets from various sources is the capital structure of the firm.

Mehmet and Eda (2009) tested whether aggregate leverages level of the sector and leverages level of sector leader are effective on capital structure decision of selected firms and sector listed in ISE. There was a dependence on behavioural finance as a supplementary approach to traditional finance to capital structure.

Boodho (2009) identified that there has always been disagreement among finance scholars when it comes to the subject of capital structure. So far, researchers have not yet reached an agreement on the optimal capital structure of firms by concurrently dealing with the agency problems.

Iyer and Agarwal (2007) recognized that optimal capital structure inhibited by industry dynamics with a single objective of increasing the value of the firm. Strebuleav (2007) also found that higher business risk, bankruptcy cost, and lower tax advantage all diminish optimal leverage.

Dasgupta and Hilary (2006) resolute on credit ratings and analyst follows up as the influencing factors determining capital structure adjustment which contributed to cost and ultimately the value of the firm.

Fakher et al. (2005) provided further substantiation of the capi-tal structure theories pertaining to a developing country and examined the impact of the lack of secondary capital market by analyzing a capital structure question with reference to the Libyan business environment.
Keshar and Baral (2004) examined the determinants of capital structure-size, business risk, growth rate, dividend payout, debt services capacity, and operating leverage of companies listed in Nepal Stock Exchange Ltd. Eight variables on multiple regression models have been used to find out the influence of defined explanatory variables on capital structure.

Fama Eugene F. (1998) explained the two internal rates of return for the non-financial sector. The return on the cost of their investment and the return on the cost delivered by the firm on the investment outlays. The return on the value is an overall cost of capital i.e return on the investment required by the capital market. The estimate of the corporate cost of capital for the 1950-96 is 10.72 .

Hutchinson Robert W. (1995) argued that a greater emphasis might usefully be placed on the cost of capital dimension in the future research into small business financing. He has also suggested that the objective of an owner manager is to control the firm, the inter-dependent investment and financing strategies may be chosen to control the cost of capital of small firms.

Singal and Mittal (1993) identified that asset mix, business risk, growth rate, earning rate, industry class, debt services capacity and corporate size are the important factors of shareholders wealth maximization.

Asquith and Mullin (1986); Baker and Wurgler (2002); Jung, Kim, and Stulz (1996); Mickelson and Partch (1989); and Marsh (1982) recognized that firms have a preference to issue equity rather than debt when stock prices are high.

Venkatesan (1983) researched the determinants of financial leverage by analyzing the relationship between seven different variables and the financial structure of the firms. The variables included industry group, size, operating leverage, debt coverage, cash flow process, business risk, and 
growth rate. Industry influence has been examined on the grouping of firms in various leverage segments and he found a statistical association between industry class and leverage, but the relationship could not be significant and conclusive. The impact of the independent variables on the dependent variable was tested in 2 samples classification, viz. intra-industry with the use of multiple regression analysis and inter-industry with the use of multiple regression analysis. In summation, only debt coverage ratio was found to be the important variable which significantly affects the financial structure of the firms.

\section{METHODOLOGY}

\subsection{Research Method}

Descriptive

\subsection{Data Collection Methods}

The data required for this analysis is secondary in nature which is collected from the official websites of companies, journals, and articles published by the various research organization.

\subsection{Sampling Technique}

\section{Convenience Sampling}

\subsection{Sample Size}

There are approx. 20 major cement companies listed in Bombay Stock Exchange. The researcher selected only 5 companies for study as a sample. The study is done for 5 years 2011-2016 on the basis of market capitalization.

\subsection{Objectives of Research}

1. To recognize the optimum capital structure of cement companies.

2. To analyze the effect of leverage on shareholders wealth.

\subsection{Statistical Tools}

The general form of the panel data model can be specified more compactly as follows:

$$
\mathbf{Y}_{\mathrm{it}}=\boldsymbol{\alpha}+\boldsymbol{\beta} \mathbf{X}_{\mathrm{it}}+\mathbf{u}_{\mathrm{it}}
$$

The subscript " $i$ " represents the cross-sectional dimension and $\mathrm{t}$ denoting the time-series dimension. The left-hand variable $\mathrm{Y}_{\mathrm{it}}$, represents the dependent variable in the model and $X_{i t}$ contains the set of independent variables in the estimation model, is taken to be constant overtime ' $t$ ' and specific to the individual crosssectional unit ' $i$ '.

$$
\mathrm{EPS}=\beta_{0}+\beta_{1} \mathrm{ER}+\beta_{2} \mathrm{DR}+\beta_{3} \mathrm{LR}+\varepsilon
$$

Where;

EPS $=$ Earnings per share

$\hat{\mathrm{a}}_{0}, \hat{\mathrm{a}}_{1}, \hat{\mathrm{a}}_{2}, \hat{\mathrm{a}}_{3}-$ Model coefficients

$\mathrm{ER}=$ Equity ratio which is total equity divided by total asset.

$\mathrm{DR}=$ Debt ratio which is total long-term debt divided by the total asset.

LR = Leverage Ratio which debt to equity

$\AA=$ Error term

\subsection{Hypotheses}

The following hypotheses have been developed for testing.

$\mathrm{H}_{1}$ : There is a negative relationship between the equity ratio and earnings per share.

$\mathrm{H}_{2}$ : There is a positive relationship between the earning per share and debt ratio

$\mathrm{H}_{3}$ : There is a positive relationship between the debt to equity ratio and earnings per share.

\section{STATISTICAL ANALYSIS}

Table-1: Descriptive Statistics

\begin{tabular}{|c|c|c|c|c|c|c|}
\hline & $\mathbf{N}$ & Minimum & Maximum & Mean & Std. Deviation & Variance \\
\hline ER & 5 & .52 & .97 & .6920 & .17079 & .029 \\
\hline DR & 5 & .00 & .12 & .0496 & .05046 & .003 \\
\hline LR & 5 & .00 & .29 & .1170 & .12814 & .016 \\
\hline EPS & 5 & 1.80 & 27.80 & 12.8280 & 11.50817 & 132.438 \\
\hline Valid N (listwise) & 5 & & & & & \\
\hline
\end{tabular}

In table 1 it is identified that standard deviation of EPS is 11.5 which is high itself, so it is concluded that EPS of cement companies varies in nature, similarly variance is 132.438 . EPS ranges from 1.80 per share to 27.80 per share. 
Standard deviations of ER, DR, LR are $0.17,0.05$, and 0.12 respectively. Mean of ER, DR, LR is $0.69,0.04,0.11$ respectively. Lowest point of Equity Ratio is 0.52 to 0.97 .

\subsection{Correlation Analysis}

Table-2: Correlation

\begin{tabular}{|c|c|c|c|c|c|}
\hline & & EPS & ER & DR & LR \\
\hline \multirow{5}{*}{ EPS } & Pearson Correlation & 1 & -.539 & -.023 & .059 \\
\hline & Sig. (2-tailed) & & .349 & .970 & .924 \\
\hline & Sum of Squares and Cross-products & 529.752 & -4.236 & -.054 & .350 \\
\hline & Covariance & 132.438 & -1.059 & -.013 & .088 \\
\hline & $\mathrm{N}$ & 5 & 5 & 5 & 5 \\
\hline \multirow{5}{*}{ ER } & Pearson Correlation & -.539 & 1 & -.511 & -.556 \\
\hline & Sig. (2-tailed) & .349 & & .379 & .330 \\
\hline & Sum of Squares and Cross-products & -4.236 & .117 & -.018 & -.049 \\
\hline & Covariance & -1.059 & .029 & -.004 & -.012 \\
\hline & $\mathrm{N}$ & 5 & 5 & 5 & 5 \\
\hline \multirow{5}{*}{ DR } & Pearson Correlation & -.023 & -.511 & 1 & $.989^{* * *}$ \\
\hline & Sig. (2-tailed) & .970 & .379 & & .001 \\
\hline & Sum of Squares and Cross-products & -.054 & -.018 & .010 & .026 \\
\hline & Covariance & -.013 & -.004 & .003 & .006 \\
\hline & $\mathrm{N}$ & 5 & 5 & 5 & 5 \\
\hline \multirow{5}{*}{ LR } & Pearson Correlation & .059 & -.556 & $.989^{* *}$ & 1 \\
\hline & Sig. (2-tailed) & .924 & .330 & .001 & \\
\hline & Sum of Squares and Cross-products & .350 & -.049 & .026 & .066 \\
\hline & Covariance & .088 & -.012 & .006 & .016 \\
\hline & $\mathrm{N}$ & 5 & 5 & 5 & 5 \\
\hline
\end{tabular}

Correlation Matrix in table 2 shows that EPS has a positive correlation with Leverage Ratio 0.059, this is not a big figure, but it is positive which means a change in leverage will change in EPS. The correlation with EPS with ER is -0.539 and EPS with DR are -0.023, with ER and DR EPS have a negative correlation.

\subsection{Regression Model Analysis}

Table-3: Model Summary

\begin{tabular}{|c|c|c|c|c|}
\hline Model & R & R Square & Adjusted R Square & Std. Error of the Estimate \\
\hline 1 & $.718^{\mathrm{a}}$ & .516 & -.935 & 16.00939 \\
\hline \multicolumn{4}{|l}{ a. Predictors: (Constant), LR, ER, DR } \\
\hline
\end{tabular}


Table-4: ANOVAa

\begin{tabular}{|c|c|c|c|c|c|c|}
\hline & Model & Sum of Squares & & Mean Square & $\mathbf{F}$ & Sig. \\
\hline \multirow{3}{*}{1} & Regression & 273.451 & 3 & 91.150 & .356 & $.808^{\mathrm{b}}$ \\
\hline & Residual & 256.300 & 1 & 256.300 & & \\
\hline & Total & 529.752 & 4 & & & \\
\hline \multicolumn{7}{|c|}{ a. Dependent Variable: EPS } \\
\hline \multicolumn{7}{|c|}{ b. Predictors: (Constant), LR, ER, DR } \\
\hline
\end{tabular}

Table-5: Coefficients

\begin{tabular}{|c|c|c|c|c|c|}
\hline \multirow[t]{2}{*}{ Model } & \multicolumn{2}{|c|}{$\begin{array}{c}\text { Unstandardized } \\
\text { Coefficients }\end{array}$} & \multirow{2}{*}{\begin{tabular}{|c}
$\begin{array}{c}\text { Standardized } \\
\text { Coefficients }\end{array}$ \\
Beta \\
\end{tabular}} & \multirow[t]{2}{*}{$\mathbf{t}$} & \multirow[t]{2}{*}{ Sig. } \\
\hline & B & Std. Error & & & \\
\hline (Constant) & 45.036 & 46.276 & & .973 & .509 \\
\hline ER & -38.983 & 59.568 & -.579 & -.654 & .631 \\
\hline$\overline{D R}$ & -612.987 & 1130.931 & -2.688 & -.542 & .684 \\
\hline LR & 215.146 & 460.816 & 2.396 & .467 & .722 \\
\hline
\end{tabular}

Multi regression analysis is based on independent and dependent variable EPS (dependent) and ER, $\mathrm{DR}, \mathrm{LR}$ are the independent variable. $\mathrm{R}$ square value is 0.516 which denotes about $51.6 \%$ of observed unpredictability in EPS can be explained by the differences in the independent variables. Other $48.4 \%$ variance in EPS depends on other factors. Further, negative beta coefficient $\mathrm{ER}(-.579), \mathrm{DR}(-2.688)$, this reflects that if equity ratio and debt ratio both increases than EPS will increase, on the other hand beta coefficient is positive for leverage ratio (2.396) means an increase in LR will increase in EPS.

\begin{tabular}{|c|c|c|}
\hline Hypothesis & Beta Coefficient & Result \\
\hline H1 & -.579 & ACCEPT \\
\hline H2 & -2.688 & REJECT \\
\hline H3 & 2.396 & ACCEPT \\
\hline
\end{tabular}

\section{CONCLUSION OF RESEARCH}

This research paper is based on the relationship between different financial ratios and relationship of these ratios with Earning per Share. The analysis is based on cement companies in India. The author found that advantage is a very important factor, which positively affects the EPS. There is a negative correlation between ER and EPS; DR and EPS, while the positive correlation between LR and EPS. Shareholder's wealth is most critical factor in today's world.

While testing the hypothesis, $\mathrm{H} 1$ and $\mathrm{H} 3$ are accepted while $\mathrm{H} 2$ is rejected. This shows that when we increase the financial leverage in our capital structure, it will help to increase the shareholder's value. The result of this research does match with the result of Srinivasan N (2013) research report. Further research on this topic will help the industries to analyze the importance of optimum leverage.

\section{REFERENCES}

[1] (n.d.). Retrieved from www. moneycontrol.com.

[2] IM, P. (1993). Financial Management. New Delhi: Vikas Publishing House Pvt Ltd.

[3] Aswath, D. (2009). Corporate Finance Theory And Practice (2nd Ed.). New Delhi: Wiley India Pvt Ltd.

[4] G.S, N. (2015). A Study On Financial Leverage And Its Impact On Earnings Per Share. Global Journal of Finance and Management, 7 (1), 25-28.

[5] Khan and Jain. (2005). Basic Financial Management. (Second, Ed.) New Delhi: Tata Mcgraw Hill.

[6] N, S, and S, R. (2013). Capital Structure and EPS: A study on Selected Financial Institutions Listed on Colombo Stock Exchange in Srilanka. European Journal of Business and Management, 5 (14), 6973.

[7] Nawaz, A., Atif, S., and Aamir, S. (2015). Impact of Financial Leverage on Firms' Profitability: An investigation from Cement Industry in Pakistan. Research Journal of Finance and Accounting, 6 (7), 75-79.

[8] P, A. D. (2009). Statistical Tools For Managers. New Delhi: Excel Books.

S, P. D. (2016, JANUARY). The Impact of Leverage on Shareholders' Wealth of Automobile. Pacific Business Review International, 79-92. 
